679 ANTIGEN ABSORPTION IS ENHANCED DURING VIRAL ENTERITIS David J. KeTjo, Kurt J. Bloch, Margot Bloch, Mimi Arrighi and J. Richard Hamilton, $\frac{\text { Margot Bloch, }}{\text { Division Gastroen- }}$ terology, Res. Inst., Hosp. Sick Children, Dept. Pediatr, Univ. Toronto, Toronto, Ont, Can; Dept. Clin Studies, Ont. Vet. Coll., Univ., Guelph, Guelph Ontario, Can; and Clin. Immunol. and Allergy Unit, Med. Service, Mass. Gen. Hosp., Boston. (Spon: Joseph B. Warshaw).

We examined the absorption of bovine serum albumin from the intestines of 2 week old piglets before and during the course of experimentally induced transmissible gastroenteritis virus infection. Blood levels of immunoreactive bovine serum albumin were measured before and 4 hours after administration of 1 gram per kilogram of bovine serum albumin through a surgically impianted jejunal catheter. The apparent permeability to the albumin was elevated during both the early invasive phase 12 albumin was elevated during both the early invasive phase 12
hours post inoculation with virus, and the diarrheal phase 84 hours post inoculation. In some animals, the elevation persisted into the recovery phase 336 hours post inoculation. The absorbed immunoreactive bovine serum albumin moved with the 70,000 molecular weight fraction on gel chromatography. Once absorbed, the albumin was cleared very slowly from the infected animals circulation, with a half life of $8-15$ days. We conclude that circulation, with a half ife of $8-15$ days. We conclude that antigen absorption is enhanced during viral enteritis. We
speculate that immune responses to this absorbed antigen might serve to prolong the disease state.
682 PROSPECTIVE HIGH VS LOW CALCIUM AND PHOSPHORUS WITH FIXED Steichen, Michael Farrel1, John W.K. Koo, Korthy, Reginald C. Tsang, Jean

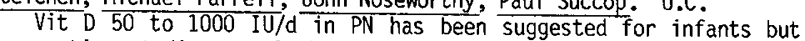
prospective studies are lacking. Effects of high or low $\mathrm{Ca}$ and $\mathrm{P}$ on Ca metabol ism have not been examined. We hypothesized that high Ca and $P$ with low vit $D$ in $P N$ results in normal $C a, P$ and vit $D$ metabolism in infants. $12 \mathrm{wt}$ appropriate for gestation infants (3M, $9 \mathrm{~F}$; $11 \mathrm{~W}, 1 \mathrm{~B}) ; 32-41$ wks; $1780-3630 \mathrm{~g}$ at birth with surgical indications for PN received fixed ' $l 0 w^{\prime} 25 \mathrm{IU}$ vit $\mathrm{D}_{2} / \mathrm{dl}$ and were randomized to either high Ca $60 \mathrm{mg}$ and $P \quad 46.5 \mathrm{mg} / \mathrm{dl}$, or $10 \% \mathrm{Ca} 20 \mathrm{mg}$ and $P 15.5 \mathrm{mg} / \mathrm{dl}$ content. Measures were made at start, $10 \mathrm{~d}$, 3wks and 6wks. There were no differences in serum $\mathrm{Ca}, \mathrm{Mg}, \mathrm{P}$, alkaline phosphatase, parathyroid hormone, calcitonin, and values were nomal. Mean serum 25 hydroxyvit $D$ mone, calcitonin, and values were normal. Mean serum 25 hydroxyvit $D$
(25OHD, protein binding) was $16-39$ for high and $15-31 \mathrm{ng} / \mathrm{ml}$ for low Ca,P grp. Mean serum 1,25 dihydroxyvitamin D $(1,25(\mathrm{OH}), \mathrm{D}$, HPLC-binding) and tubular reabsorption $P$ (TRP) in high Ca, $P$ grp were stable $72-47 \mathrm{pg} / \mathrm{ml}$, and, $88-80 \%$ resp; values in low Ca, $\mathrm{P}$ grp were higher $78-127 \mathrm{pg} / \mathrm{ml}$ and $75-99 \%$ ( $<<0.05$ covariance, high $\vee$ low). Urine $\mathrm{Ca}$ and $\mathrm{Mg} /$ Creatinine were not different between grps. 5 infants on $\mathrm{PN}$ for 71-175d with same vit and low Ca,P had normal 250HD with high TRP and $1,25(\mathrm{OH})_{2} \mathrm{D}$. Thus, PN with 1) low $25 \mathrm{IU}$ vit $\mathrm{D} / \mathrm{dl}$ maintains nomal serum 250HD for up to 6mos 2) high Ca,P similar to that absorbed from human milk results in stable serum $1,25(\mathrm{OH})_{2} \mathrm{D}$ and TRP. We speculate that low $\mathrm{Ca}, \mathrm{P}$ intake results in adaptive increase in $1,25(\mathrm{OH}) \mathrm{D}$ and TRP reflecting insufficient $\mathrm{Ca}$ and $\mathrm{P}$ intake; and high $\mathrm{Ca}$ and $\mathrm{P}$ may benefit bone mineralization in long term PN. 680 MIXING CARBOHYDRATES(CHO) - ADDITIVE AND COMPETITIVE Gary Birken, Anton $H$. A A laboun $i, H$. Juhling McCiung. ohio State Univ. Coll. of Medicine,Dept. Peds, Columbus,, $\mathrm{OH}$. When intestinal absorptive function is 7 imited, it may be possible to enhance CHO absorption by combining CHOs having different digestive-absorptive pathways. Employing single pass perfusion studies in partially atrophic amploying single pass perThiry-Vella fistulae we found that absorption of glucose (G) sucrose( $S$ ), and long chain glucose polymers (LCGP) was saturable with infusion conc. of 882,378 , and $347 \mathrm{mg} / \mathrm{dl}$ respectively. Absorption of $S$ and LCGP was additive even from solutions containing $900 \mathrm{mg} / \mathrm{d}$ ) of each sugar $(S=159 \pm 16, L C G P=70 \pm 6$, mixture $=235 \pm 22$ $\mu \mathrm{gms} / \mathrm{cm} / \mathrm{min}$.). Virtually no $G$ was found in the fistula effluents $(<0.1 \mathrm{mg} / \mathrm{ml})$. Adding $900 \mathrm{mg} \mathrm{S}$ to $900 \mathrm{mg}$ LCGO did not improve CHO absorption beyond values for $900 \mathrm{mg} / \mathrm{dl}$ of $G$ infused alone $(378+16$ ugms $/ \mathrm{cm} / \mathrm{min}$.). Addition of the $V_{\text {man }}$ conc. $(400 \mathrm{mg} / \mathrm{d} 7)$ of LCGP to the $V$ max conc. of $G(900 \mathrm{mg} / \mathrm{dl})$ ) caluses mutual inhibition of the absorpti on of both (G, $346 \pm 23$ vs. $232 \pm 25$; LCGP, $63 \pm 8$ vs. 28 ; $\mathrm{p}<.001)$. Additive absorption occurs with addition of $400 \mathrm{mg} / \mathrm{dl}$ LCGP to $500 \mathrm{mg} / \mathrm{dl}$ of $\mathrm{G}$ ( $(L G P=56 \pm 8, G=152 \pm 8$, mixture $=208 \pm 10$ ). Con-
clusions: 1) For G polymers and $S$, hydrolys is, not absorption of clusions: 1)For $G$ polymers and $S$, hydrolysis, not absorption of similation. 2) $G$ and LCGP either interact in the for jejunal ascompete for absorptive pathways. 3)S does not compete with LCGP for absorption. Speculation: In formulating enteral feedings or rehydration soiutions mixtures of $S$ and LCGP may enhance absorption, but addition of LCGP to G may be deleterious.

\section{$\dagger 681$}

INHIBITION OF MALTOPENTAOSE (MP) ABSORPTION BY MEDIUM (CSH). Benny Kerzner, Howard R. SloanCH HYDROL YSATE Constance Seckel, Gary Birken, $H$. Juhling Mcclung. Ohio State Univ. College of Medicine,Dept. Peds., Columbus, $\mathrm{OH}$.

To define optimal carbohydrates for infants with limited pancreatic and intestinal pycosal function we synthesized and evalu ated the absorption of ${ }^{14}$ C-MP - a giucose oligomer ideally suited to glucoamylase activity. Representative medium (degree of polymerization, DP, 4-9) and long chain (DP.75) polymers were isnlated from a CSH. Using partially atrophic, pancreatic amylasefree, canine, jejunal, Thiry-Vella fistulae, absorption of DP 5 was measured: a lone, in the presence of $90,180,270,360$ and 450 $\mathrm{mg} / \mathrm{dl}$ of DP 4-8, with similar concentrations of DP \pm 75 and with $450 \mathrm{mg} / \mathrm{dl}$ of sucrose. Results: Absorption of DP 4-8 was greater than sucrose which exceeds $D \mathrm{P} \pm 75$. A though at $450 \mathrm{mg} / \mathrm{dl}$ there was equivalent inhibition of DP 5 absorption by DP $4-8(46 \%)$ and $D P \pm 75(45 \%)$, at $90 \mathrm{mg} / \mathrm{dl}$, inhibition by DP $4-8$ was significantly less than by DP 75 ( 10 vs. 27\%, $p<.01)$. Sucrose did not inhibit DP 5 absorption $(p<.001)$. Conclusions: 1)ATthough assimilation of glucose polymers is less efficient than shorter oligomers, both inhibit DP 5 absorption. 2) At low concentrations the greater inhibition by $\mathrm{DP} \pm 75$ probably reflects a protracted affinity for the glucoamylase enzyme. 3) Sucrose does not compete for oligomer assimilation. Speculation: These results suggest that substitution of sucrose for a portion of the polymers in a CSH, especially the long chain elements, will improve carbohydrate absorption.
683 NATURAL HISTORY OF RICKETS AND FRACTURES IN VERY LOW

683 BIRTH WEIGHT (VLBW) INFANTS DURING INFANCY. Winston Sherman and Jean Steichen. University of Cincinnati Medical Center. Radiographic bone demineralization (BD), rickets $(R)$ and fractures (F) have been noted anecdotally in VLBW infants but there is no prospective study of the course and outcome of the skeletal pathology. We hypothesized that $B D, R$ and $F$ are frequent in VLBW infants, but the lesions are self resolving with time. X-rays from $60 \mathrm{VLBW}$ (birth wt $<1500 \mathrm{~g}$ ) infants were taken prospectively. Birth wts were $580-1500 \mathrm{~g}$, gestation 24-34wks; 32B, 28W; 54 AGA and 6 SGA. Single view $x$-rays were taken of both forearms at $3,6,9$ and 12 mos. Other $x$-rays taken for clinical reasons also were reviewed. $B D, R$ and $F$ were determined using standard criteria. 'Mild' BD was regarded as normal. From 40 infants who completed the study BD occurred in $22.5 \%, R$ in $17.5 \%, F$ in $20 \%$. BD was noted in all infants with $R$ or $F$. All infants with $R$ had $F$ but only one infant had $F$ without $R$. All abnormal $x$-rays were noted by 6 mos, $75 \%$ by 3 mos and one infant by 7 wks. F occurred predominantly in extremities ( 8 radius and/or ulna, 3 humerus, 3 femur), 5 ribs; unusual sites included 1 scapula; 5 had multiple $F$. Prior to radiographic changes, 60\% received parenteral nutrition (calcium 20mg, phosphorus $15.5 \mathrm{mg} / \mathrm{dl}$, vit $\mathrm{D}_{2} 20 \mathrm{IU} / \mathrm{kg} / \mathrm{d}$ ); $70 \%$ received own mother's mi $1 \mathrm{k}$ or standard $20 \mathrm{kcal} / \mathrm{oz}$ formula; $30 \%$ received high calcium and phosphorus formulas in varying quantities. By 9 mos all $\mathrm{F}$ and $\mathrm{R}$ healed regardless of mode of therapy or diet. By 12 mos, 1 infant only still had BD. We conclude 1) BD, R and $F$ are present in 1 in 5 of VLBW infants; 2) infants with rickets are likely to have fractures; 3) if one fracture is noted other fractures are likely. Until definitive preventive measures become available, we suggest care be taken during physical manipula-
tion of these infants.

684 PANCREATIC FLUID SECRETION IN CYSTIC FIBROSIS (CF). H.Kopelman, M.Corey, K.Gaskin, P.Durie, and G. Forstner. Hospital for Sick Chitdren, GIDiv., Dept. Ped. and Kinsmen CF Res. Center, Toronto. (Sponsored by Dr. K. N.Drummond, Montreal Children's Hospital, Dept. Ped., Montreal). The cause of exocrine duct obstruction in CF is uncertain. To evaluate the role of impaired fluid secretion in the pathogenes is of pancreatic duct obstruction, we examined the relation of fluid secretion to protein output in $C F$ and in control pts. with equivalent pancreatic function (tryps in output). A quantitative marker perfusion technique was used for collection of duodenal contents during pancreatic stimulation with secretin and CCK.

Water secretion in $55 \mathrm{CF}$ pts. $(3.15 \pm 2.58 \mathrm{ml} / \mathrm{kg} / \mathrm{hr})$ was less than in 57 non-CF controls $(10.48 \pm 5.23 \mathrm{ml} / \mathrm{kg} / \mathrm{hr}, p<0.0001)$. Flow was correlated with trypsin output in $C F(r=0.66, p<0.0001)$ and non-CF $(r=0.51, p<0.0001)$ pts. By analys is of covariance, the slopes were identical but the CF adjusted mean flow, correcting for trypsin output, was $41 \%$ of the non-CF value. Water secretion correlated with $\mathrm{HCO} 03$ output in $\mathrm{CF}(r=0.77, p<0.0001)$ and non-CF $(r=0.67, p<0.0001)$ pts. Protein output was independent of flow in 21 non-CF pts. $(r=0.22, p>0.1)$ but was related to H2O secretion $(r=0.84, p<0.001)$ in 28 CF pts. By multiple linear regression analyses, the effect of flow on protein output was independent of trypsin.

Conclusions: 1. Flow is diminished in CF independent of pancreatic acinar impairment. 2. Defective HCO3 output may account for the defect in fluid secretion. 3. Protein output in CF is dependent on flow. The data suggest that impaired flow in $\mathrm{CF}$ leads to protein stasis within ducts. 